Meetings of Section IV (Geological Sciences) were attended by twenty members and some dozen non-members, including officers of the Geological Division of the Quebec Bureau of Mines. Announcement was made of the award of a Royal Society Carnegie fellowship to V. J. Okulitch, of the University of British Columbia and McGill University, who proposes to carry on research at Harvard University.

Twenty-six papers were read or presented by title at the several sessions. Among those which evoked the most interesting discussion may be mentioned papers by J. S. DeLury, on geothermal gradients and on the mechanies of igneous intrusion, and one by Prof. E. L. Bruce on the spectrographic examination of quartz from some gold-bearing quartz veins. Prof. G. H. Henderson gave a summary, illustrated by slides of photomicrographs, of two papers on pleochroic haloes in biotite, and a method of calculating from them the age of the mineral-papers he had presented before Section III of the Society. Prof. Henderson's talk was of considerable interest, and was followed by an informative discussion.

On May 23, twenty members and friends joined in a geological excursion to Levis and vicinity, conducted by Dr. B. T. Denis of the Quebec Bureau of Mines and Prof. T. H. Clark, and on the following day a number of members, at the invitation of Dr. John A. Dresser, visited the Notre Dame Mountains of Quebec, examining especially the rocks of the Serpentine Belt.

The presidential address delivered by Prof. Marie-Victorin before Section V (Biological Sciences) dealt with the flora and ecology of the different sections of the St. Lawrence River. Dr. Huntsman presented two interesting papers on the life and feeding habits of the Fundy salmon and herring respectively; apparently neither of these fish normally migrates so widely as has been supposed. A paper by R. E. Foerster reported reciprocal crosses of the five species of Pacific salmon. Several botanical papers contained results of more than usual significance. One by G. A. Ledingham announced that the zoospores of members of the Plasmodiophorales are biciliate, not uniciliate as hitherto described, and that one cilium is much shorter than the other, indicating less affinity with the Myxomycetes than has been supposed and perhaps, as was suggested in the discussion, descent from algal Heterokontæ. Further evidence of polyphyletic origin of the Fungi was contained in a paper by H. S. Jackson which demonstrated close similarity in the life cycles and sexuality of Uredinales and Rhodophyceæ. Experimental plant embryology was the subject of a paper by Prof. R. B. Thomson, who described how the haustorium of Marsilea embryos develops spherically instead of in the typical cap shape when grown in culture fluid. Prof. G. W. Scarth gave evidence of a remarkable increase in cell permeability (to urea, etc.) in plants which have become hardened to frost. A useful and comprehensive summary of work done in the U.S. Department of Agriculture on cereal rust in relation to the physiology of the host was given by Dr. H. B. Humphrey.

The papers presented to the Medical Sciences Sub-Section covered an exceptionally wide range of topics. Sir Frederick Banting's group have continued their work on silicosis with the development of valuable new methods of attack on the problem, and have found important experimental evidence against the view that sericite, rather than silica, is the harmful substance. Outstanding among a number of communications from the Connaught Laboratories was an exhaustive quantitative study of the diphtheria-antitoxin content of human sera in various circumstances, by Dr. D. T. Fraser. Prof. J. B. Collip and his collaborators presented a series of papers on anterior pituitary hormones, among which Dr. Hector Mortimer's $\mathrm{X}$-ray studies on experimentally produced changes in the rat's skull were noteworthy. Another group of papers was presented by Prof. C. H. Best, and included an account of different crystalline metallic salts of insulin by Dr. D. A. Scott. Prof. F. R. Miller reported on the effects of unipolar faradisation of the caudate nucleus; Dr. G. F. Marrian described improved methods for the isolation and chemical assay of œstrin ; and Prof. C. C. Macklin strikingly demonstrated the existence of communicating pores, in the alveolar walls, between different lobules of the lung.

\title{
Obituary
}

\section{Dr. Marion I. Newbigin}

$\mathrm{W}^{\mathrm{E}}$ regret to record the death of Dr. Marion Isabel Newbigin, which occurred in Edinburgh on July 20. The removal of her outstanding personality marks a severe loss to geographical science in Great Britain, for she exerted a powerful influence upon the development of geography throughout the present century, by her own writings and teaching as well as by her admirable editing of the Scottish Geographical Magazine since 1902.

Dr. Newbigin, who was born at Alnwick in 1869 , was one of a group of pioneer women who received university training in natural science, and after studying at University College, Aberystwyth and at the University of Edinburgh she graduated as a B.Sc. of London in 1893. Devoting herself to zoology, she quickly established a reputation by her work on pigmentation in animals. She published papers on colour in two groups of birds (Trochilidæ and Nectariniidæ), others upon the pigments of decapod Crustacea and of the muscle of salmon. For this work "and for her book "Colour in Nature, a Study in Biology" she received the degree of D.Sc.(Lond.) in 1898. Her interest in marine fauna is indicated by two papers 
and by the volume "Life by the Sea Shore, an Introduction to Natural History" (1901). Although Dr. Newbigin then turned to the rapidly developing subject of geography, she maintained contact with biology in the Royal Physical Society of Edinburgh, of which she had been secretary and president, and as extra-mural lecturer on biology at the Womens' Medical School in Edinburgh until 1916. She published a work on animal geography (1913), and over a long period acted as assistant editor of the Journal of the Royal Scottish Arboricultural Society.

Dr. Newbigin brought her knowledge of environmental influences to bear upon the study of human activities with great effect; and her numerous geographical writings possess special value because of this. Her earlier books, which were of a general character, included "Tillers of the Ground" (1910); "Modern Geography" (1911) ; and "Man and his Conquest of Nature" (1912). She travelled widely, and methodically built her careful observations into a series of valuable regional interpretations. Of special note are her works on southern Europe:
"Geographical Aspects of Balkan Problems" (1915); "Mediterranean Lands" (1924) ; and "Southern Europe" (1932).

As a lecturer in geography, Dr. Newbigin was in great demand, and in recent years she gave regular courses at Bedford College, University of London. She rarely missed an International Geographical Congress, and she attended the meetings of the British Association regularly, presiding over Section E in 1922. She was the recipient of the Back Grant of the Royal Geographical Society in 1921 and the Livingstone Gold Medal of the Royal Scottish Geographical Society in 1923. The latter Society is especially in her debt for her loyal service and her un. remitting labour in maintaining the high standard of its Magazine for thirty-two years.

WE regret to announce the death of $\mathrm{Mr}$. $\mathrm{H}$. Glauert, F.R.S., principal scientific officer at the Royal Aircraft Establishment, Farnborough, author of numerous papers on aerodynamics, on August 4, aged forty-one years.

\section{News and Views}

\section{Prof. E. G. Coker's Retirement}

Prof. E. G. Coker, who is this year retiring from the Kennedy chair of civil and mechanical engineering in University College, London, was appointed to his chair not long before the outbreak of the War, which found him in Australia, where he had gone as president of Section $G$ of the British Association. In common with a number of other scientific workers, he had some unexpectedly exciting experiences on that occasion, narrowly escaping capture by the German cruiser Emden. Prof. Coker went to University College from the City and Guilds Technical College, Finsbury, where for some years he was the colleague of Silvanus Thompson, who was associated with some of his earlier work on polarised light. Before that time he was associate professor of civil engineering in McGill University, Montreal. Prof. Coker's name is chiefly associated, in the minds of engineers, with the direct exploration of stress in machines and structures by means of polarised light, a field which he has made peculiarly his own and which has been largely built up by his own efforts.

THE double-refraction caused by stress in transparent materials was discovered more than a century ago by Sir David Brewster, and the suggestion that this effect might be used to discover the stressdistribution in such materials was actually made by Brewster himself. Attempts in this direction were undertaken at various times, for example, by Clerk Maxwell, Carus Wilson, Mesnager and others. while the laws underlying the phenomenon have been investigated by a number of physicists. It was left to Coker, however, to develop the method, and to make it, by a variety of skilful contrivances (in particular his lateral extensometer), into a really practical one. To him is due also the use of an easily workable material like celluloid for such investigations. By this means he has been able to solve a number of important problems relating to contact stresses, gears, test-pieces, architectural structures, etc., where mathematical analysus proved either inadequate or too complicated. For this work he created, at University College, a first-class research laboratory, which has attained a world-wide reputation. His recent treatise on "Photo-Elasticity", written in collaboration with his colleague, Prof. Filon, gives an exhaustive account of this subject, and embodies the results of a quarter of a century of continuous research. It is much to be hoped that this work will not be interrupted by Prof. Coker's retirement, and that he will continue, with unabated vigour and activity, to enrich engineering science in his chosen field.

\section{New Vice-Chancellor: University of Melbourne}

Mr. R. E. Priestley, fellow of Clare College, Cambridge, and Secretary General of the Faculties of the University, has been appointed Vice-Chancellor of the University of Melbourne. Mr. Priestley was educated at Tewkesbury Grammar School and entered the University of Bristol in 1905. In 1907 he joined Shackleton's Nimrod Expedition as geologist. On retuming from the Antarctic in 1909 he spent a year as a research student at the University of Sydney, working up the results of the expedition with Prof. Edgworth David. The sudden illness of Scott's geologist led to Priestley joining Scott's last expedition one week before the boat left Sydney. From 1910 until 1913 he was scientific observer with the northern party, first at Cape Adair, then at Terra Nova Bay. During the latter period 